\title{
Therapeutic Efficacy of Tyrosine Kinase Inhibitors Treatment for Metastatic Renal Cell Carcinoma Using 18F-FDG PET/CT
}

\author{
TAMER W. KASSEM, M.D. and MAGED A. HAWANA, M.D. \\ The Department of Radiology, Faculty of Medicine, Cairo University, Egypt
}

\begin{abstract}
Background: Renal Cell Carcinoma (RCC) diagnosis increased due to increased use of cross-sectional imaging studies, metastases are common in RCC. 18F-FDG PET/CT has a limited role in detection of primary RCC, but it is helpful in restaging, detection of distant metastasis and can be used in assessment of number and sites of RCC metastasis as baseline for future re-treatments.
\end{abstract}

Nowadays therapy with drugs targeting vascular endothelial growth factor receptor such as Tyrosine Kinase Inhibitors (TKI) showed promising efficacy. Response to chemotherapy has been monitored by Response Evaluation Criteria in Solid Tumors (RECIST) based on size measurements.

Aim of Study: The aim of this study was to use FDG uptake as indicator for assessment of biological response of Renal Cell Carcinoma (RCC) metastatic deposits to Tyrosine Kinase Inhibitors (TKI).

Patients and Methods: 30 patients having pathologically proven metastatic RCC in post total nephrectomy state underwent PET/CT examination at private center in period between March 2017 and April 2018 and following a preset protocol as baseline study. They all received 4 cycles (six weeks cycles) of TKI therapy then all had a second PET/CT examination following same protocol after 6 months to assess therapeutic response.

Results: Out of 30 cases 22 cases $(73.3 \%)$ showed disease regression, 6 cases $(20 \%)$ showed stationary course and 2 cases $(6.7 \%)$ showed disease progression.

Conclusion: 18 F-FDG PET/CT is an effective index in monitoring efficacy of TKI treatment for RCC metastasis.

Key Words: Tyrosine kinase inhibitors - Metastatic renal cell carcinoma -18 F-FDG PET/CT.

Correspondence to: Dr. Tamer W. Kassem, The Department of Radiology, Faculty of Medicine, Cairo University, Egypt

\section{Introduction}

RENAL Cell Carcinoma (RCC) diagnosis increased due to increased use of cross-sectional imaging studies [1]

Being resistant to radiotherapy and chemotherapy, partial or radical nephrectomy is the best way of treatment for the primary lesions [2]

Metastases are common in RCC. $30 \%$ of patients presented at diagnosis of primary lesions with evidence of metastases and more than $30 \%$ develop metastases after nephrectomy [1]

18F-FDG PET/CT has a limited role in detection of primary RCC [3], is helpful in restaging, detection of distant metastasis [4] and can be used in assessment of number and sites of RCC metastasis as baseline for future re-treatments [1]

Treatment of metastatic RCC was restricted to cytoreductive surgery, palliative radiation, interferon and interleukin [5]. Nowadays therapy with drugs targeting vascular endothelial growth factor receptor such as Tyrosine Kinase Inhibitors (TKI) showed promising efficacy. Sorafenib and sunitinib prevent angiogenesis and tumor proliferation [6]

Response to chemotherapy has been monitored by Response Evaluation Criteria in Solid Tumors (RECIST) based on size measurements. The objective of this study was to use FDG uptake as indicator for assessment of biological response of RCC metastatic deposits to TKI. 


\section{Patients and Methods}

The study was approved by the Local Ethical Committee.

A prospective study of 30 patients $(17$ females and 13 males) aged 31 to 68 years old (with mean age of 44 years old) presenting to private center in period between March 2017 and April 2018 with pathologically proven metastatic RCC in post nephrectomy state (partial or complete) was performed. All of them had a second PET/CT examination following same protocol after 6 months after finishing 4 cycles of TKI therapy (6 weeks each) to assess its therapeutic response.

There were no set criteria for referral other than histopathologic evidence of metastatic RCC after biopsy or surgery. Patients had clinical evaluation including medical history. Information regarding biopsies, surgeries and intervention was obtained from all cases.

All images were reconstructed using special software and workstations.

Each patient performed two PET/CT scan examinations following same protocol with 6 months interval. All patients were scanned using a dedicated PET/CT system (Philips 16 Release 3.5.2, Netherlands), covering axial FOV of $15.5 \mathrm{~cm}$ and a resolution of $2 \mathrm{~mm}$ in axial and $3 \mathrm{~mm}$ trans axial directions.

All patients fasted for 8 hours before the examination and were hydrated orally. Before the study, blood glucose levels were assessed and found to be within normal in all cases. First non contrast low dose $\mathrm{CT}$ images were obtained for fusion images. A $320-460 \mathrm{MBq}\left({ }^{18} \mathrm{~F}-\mathrm{FDG}\right)$ were injected. The patients rested for an uptake period (30 to 45 minutes) in relaxed position. Acquisition of PET scans from the nose to the lower thighs was performed after emptying the bladder.

Routine post intravenous non ionic contrast axial $\mathrm{CT}$ scan at $3 \mathrm{~mm}$ intervals was acquired for the chest, abdomen and pelvis for all patients at the end of the examination.

\section{Data analysis and interpretation:}

All images were reconstructed in 2D sagittal and coronal multiplanar planes and read visually. Reconstruction of raw data was done using special workstations.

All PET/CT and CT imaging was interpreted by one staff radiologist accompanied by one staff nuclear medicine. All foci of non physiologic FDG uptake were considered indicative of metastatic disease and SUV max values were calculated automatically.

\section{Results}

Different therapeutic responses were recorded as listed in Table (1). Out of 30 cases 22 cases $(73.3 \%)$ showed disease regression, 6 cases $(20 \%)$ showed stationary course and 2 cases $(6.7 \%)$ showed disease progression.

Sites of regression were noted at pulmonary nodules and lymph nodes (Figs. 1,3) as well as osseous deposits (Fig. 2). All pulmonary nodules encountered in the study showed regressive course suggesting high sensitivity to the drug.

Stationary course of metastatic deposits was recorded in lymph nodes and osseous deposits.

Progression of the disease was noted in two cases, one had bony deposits and the second had nodal metastasis and developed new peritoneal nodule proved to be metastatic by histopathology (Fig. 4).

Table (1): Different therapeutic responses in all cases, $\mathrm{n}(\%)$.

\begin{tabular}{llcc}
\hline & $\begin{array}{c}\text { Regression } \\
\text { or complete } \\
\text { resolution }\end{array}$ & $\begin{array}{c}\text { Stationary } \\
\text { course }\end{array}$ & $\begin{array}{c}\text { Progression or } \\
\text { newly } \\
\text { developed sites }\end{array}$ \\
\hline 30 patients & $22(73.3 \%)$ & $6(20 \%)$ & $2(6.7 \%)$ \\
\hline
\end{tabular}


Baseline study (post right nephrectomy)

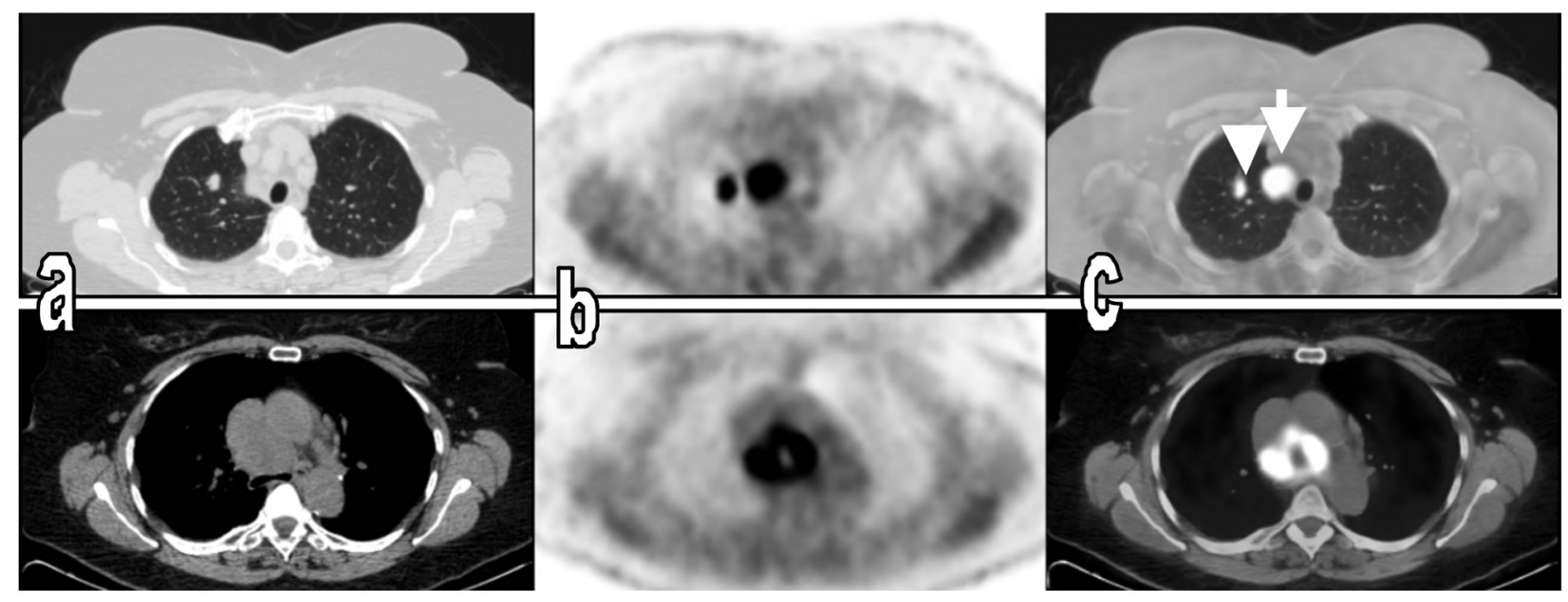

Follow-up study (after 6 months)

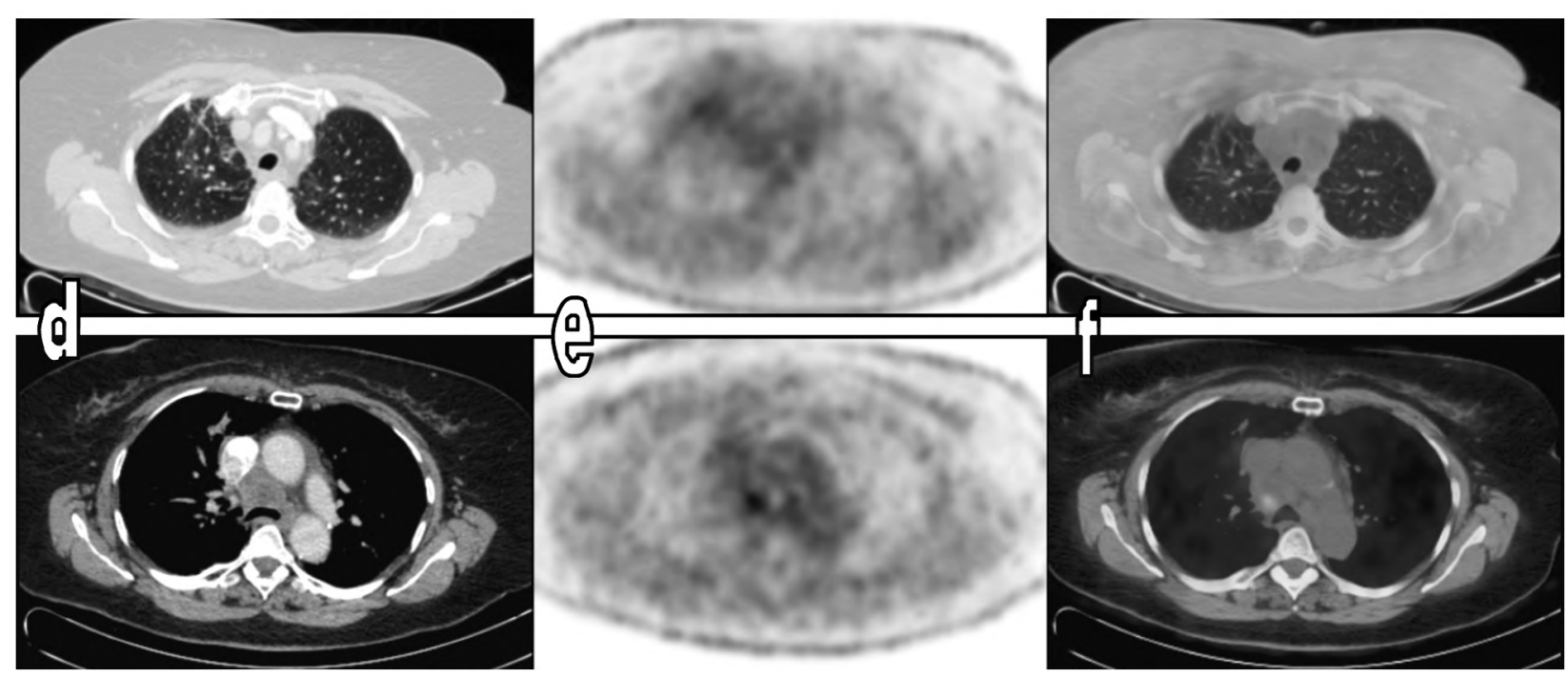

Fig. (1): A 62-year-old male patient with pathologically proven metastatic RCC pulmonary and mediastinal nodal deposits.

Baseline study post right nephrectomy: (A) Axial CT (B) Axial MIP PET image and (C) Axial fused PET/CT image.

- Hypermetabolic para-tracheal lymph node (arrow in c) measuring about 4.5 X $3.5 \mathrm{~cm}$ showing central photopenia of breaking down with SUVmax 17.6.

- Right pulmonary hypermetabolic nodule at the apical segment of the right upper lobe (arrow head in c) measuring about $1.3 \mathrm{~cm}$ in maximum transverse diameter with SUVmax 8.7.

- Follow-up study after 6 months: (D) Axial post contrast CT (E) Axial MIP PET image and (F) Axial fused PET/CT image.

- Complete metabolic and morphologic response of previously noted right upper lung lobe hypermetabolic pulmonary nodule.

- Partial metabolic and morphologic response of previously noted mediastinal nodal lesion currently measuring about $3.9 \mathrm{X}$ $3.1 \mathrm{~cm}$ with SUVmax 4.7. It demonstrates predominant photopenic center with only focal ${ }^{18} \mathrm{~F}$-FDG activity seen in its right posterior aspect. 
Baseline study (post right partial nephrectomy)
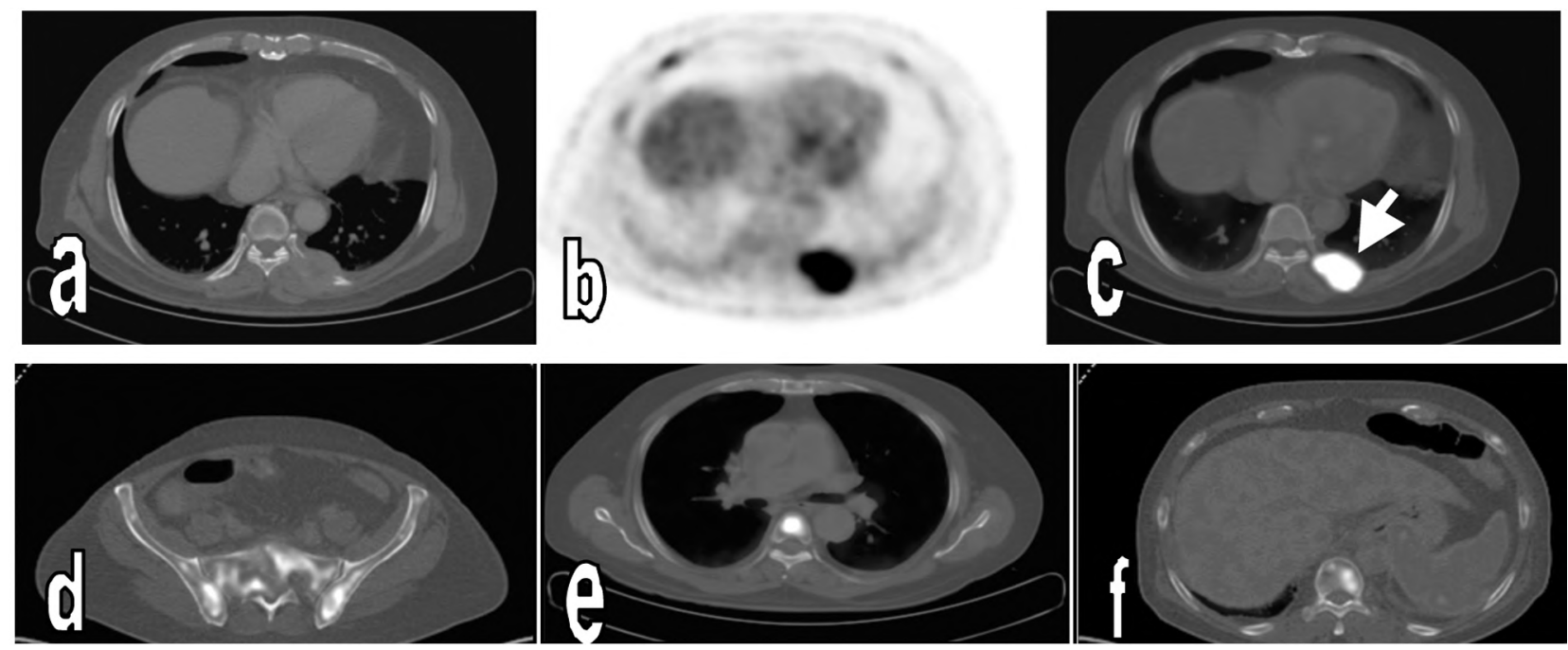

Follow-up study (after 6 months)
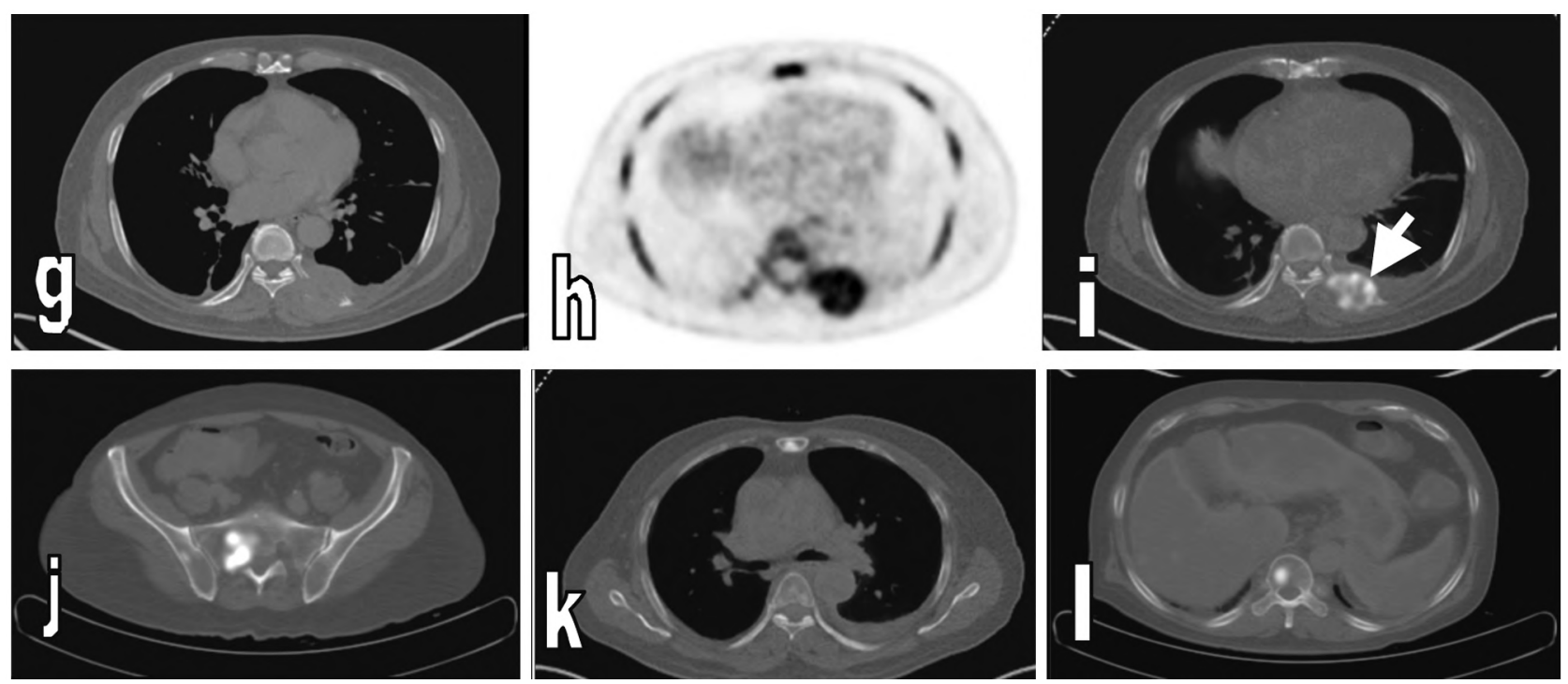

Fig. (2): A 60-year-old male patient with pathologically proven metastatic RCC bony deposits.

- Baseline study post right partial nephrectomy: (A) Axial post contrast CT (B) Axial MIP PET image and (C-F) Axial fused PET/CT images.

- Multiple hypermetabolic osseous deposits involving most of the vertebrae, ribs, sternum and pelvic bones. The most active lesion is seen at the vertebral end of left 8 th rib with soft tissue component and SUVmax 8.9 (arrow in c).

- Follow-up study after 6 months: (G) Axial post contrast CT (H) Axial MIP PET image and (I-L) Axial fused PET/CT images.

- Metabolic and morphologic regression of osseous lesions. The most active lesion at the vertebral end of left 8 th rib with soft tissue component and SUVmax 6.2 (arrow in i). 
Baseline study (post right nephrectomy)
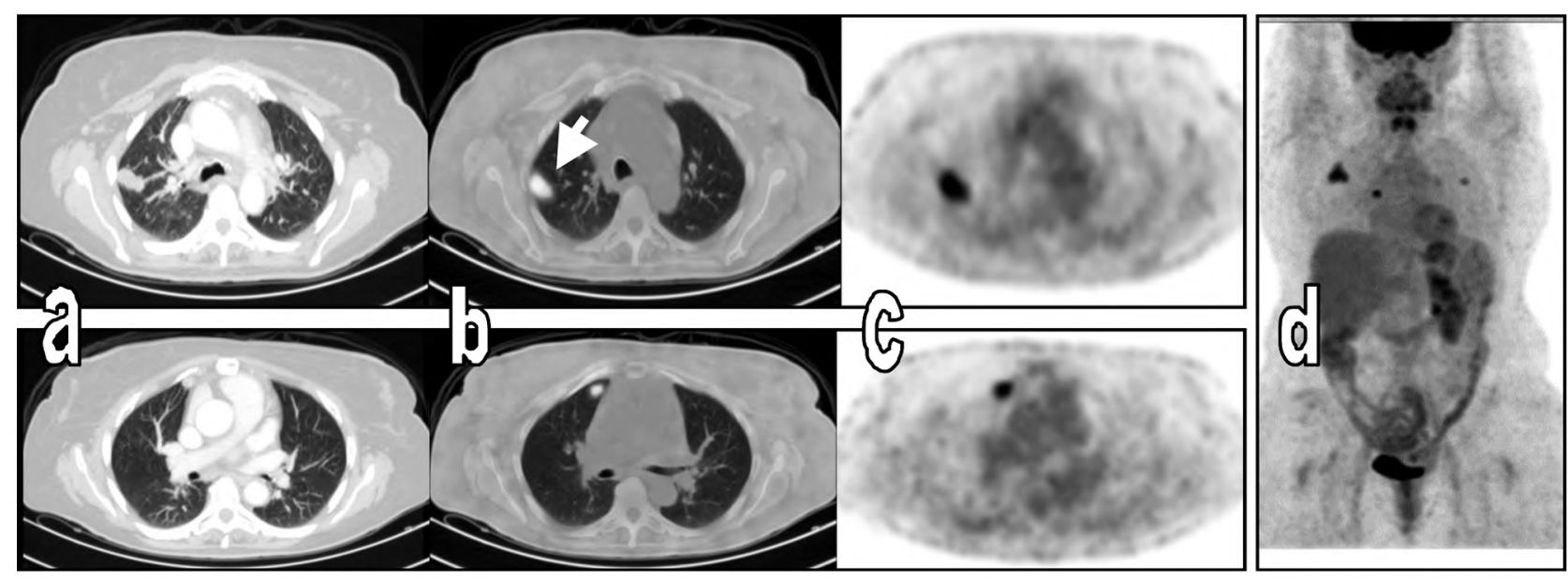

Follow-up study (after 6 months)
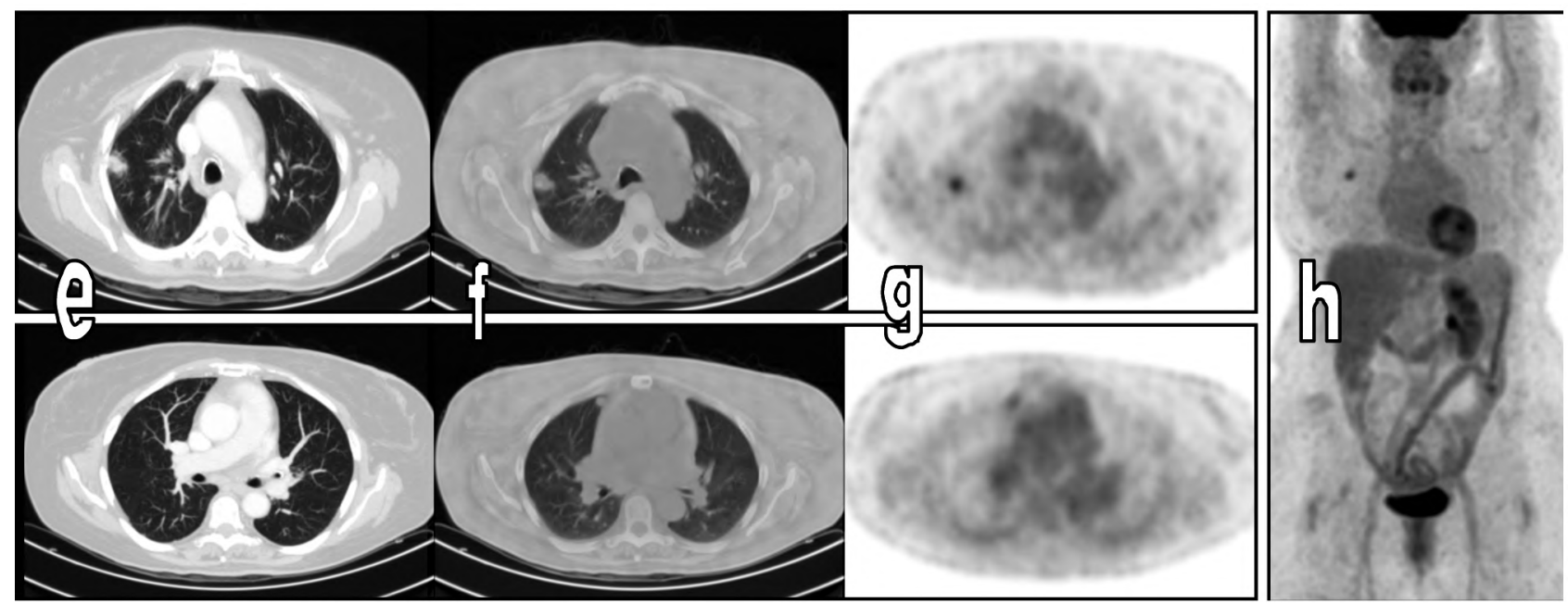

Fig. (3): A 48-year-old male patient with pathologically proven metastatic RCC pulmonary deposits.

- Baseline study post right nephrectomy: (A) Axial post contrast CT (B) Axial fused PET/CT images (C) Axial MIP PET image and (D) Coronal MIP PET image.

- Multiple bilateral upper lung lobes nodules. The most active at right lung located at the posterior segment of right upper lobe (arrow in b) having SUVmax 7.9 and measuring about $2.5 \mathrm{~cm}$ in diameter.

- Follow-up study after 6 months: (E) Axial post contrast CT (F) Axial fused PET/CT images (G) Axial MIP PET image and (H) Coronal MIP PET image.

- Metabolic and morphologic regression of the previously noted multiple bilateral upper lung lobes nodules. The currently most active at right lung located at the posterior segment of right upper lobe having SUVmax 3.4 and measuring about $1.4 \mathrm{~cm}$ in diameter. 
Baseline study (post left nephrectomy)
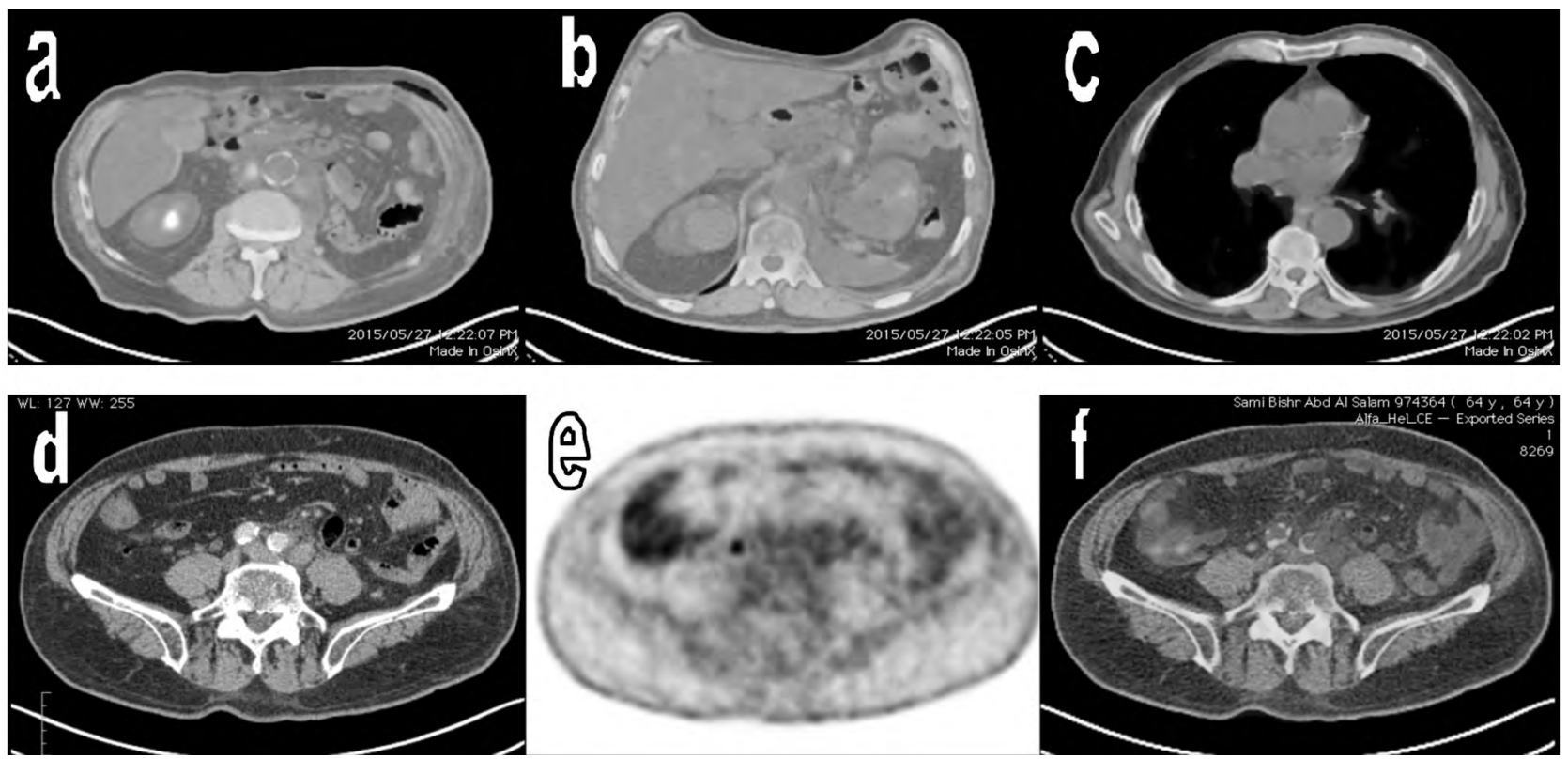

Follow-up study (after 6 months)
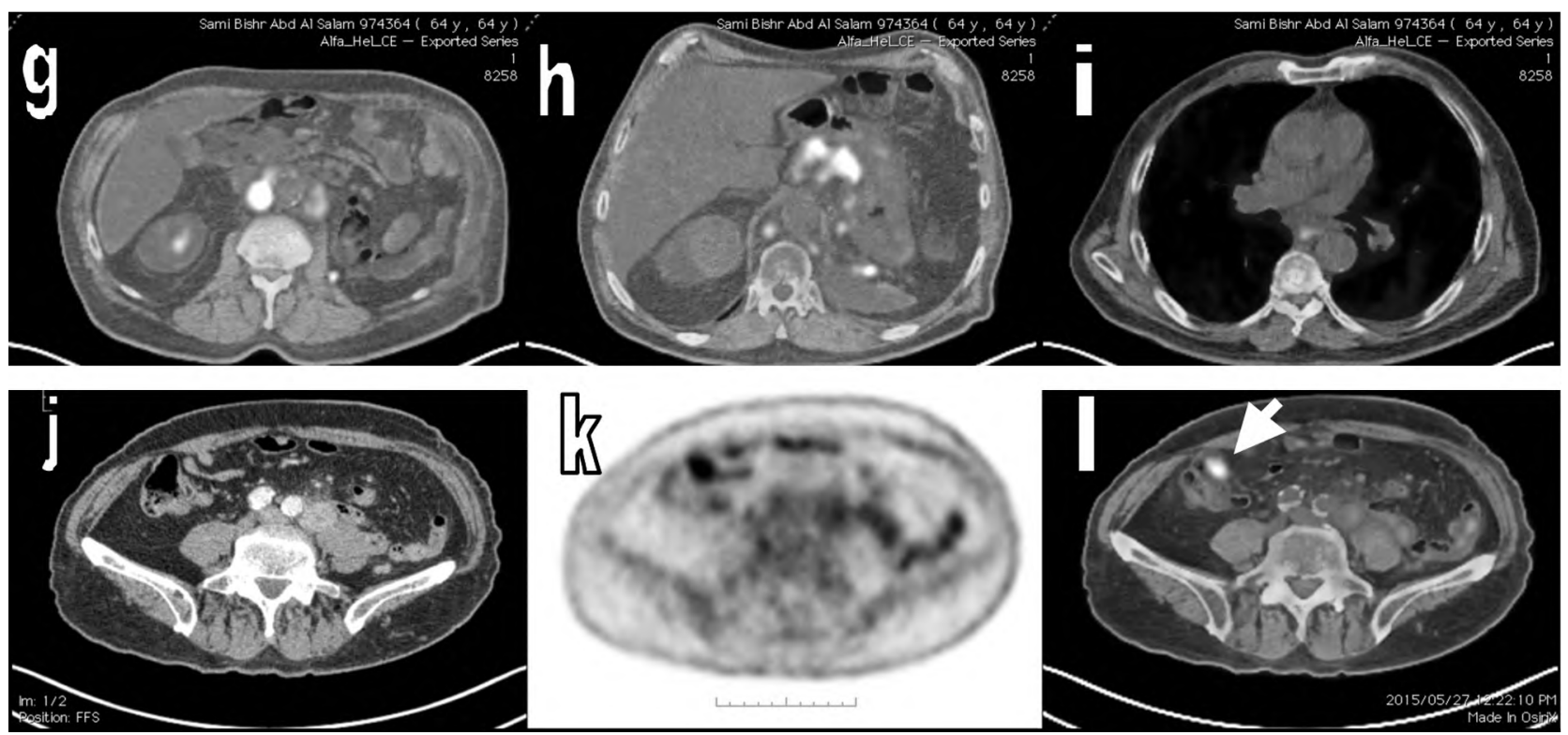

Fig. (4): A 54-year-old male patient with pathologically proven metastatic RCC nodal deposits.

- Baseline study post left nephrectomy: (A-C,F) Axial fused PET/CT images (D) Axial post contrast CT (E) Axial MIP PET image.

- Multiple FDG-avid infra diaphragmatic lymphadenopathy. Multiple partly amalgamated left gastric and mesenteric nodes with SUVmax 4.9. Multiple left para-aortic and aorto-caval nodes, the latter with SUVmax 5.4.

- Follow-up study after 6 months: (G-I,L) Axial fused PET/CT images (J) Axial post contrast CT (K) Axial MIP PET image.

- Metabolic and morphologic progression of the previously noted hypermetabolic lymph nodes. The left gastric and mesenteric nodes have current SUVmax 9.5 over left gastric. The aorto-caval nodes have current SUVmax 19.0.

- Newly developed increased FDG uptake by left iliac fossa soft tissue peritoneal nodule along serosa of bowel loops (arrow in 1$)$ measuring $1.4 \mathrm{~cm}$ in diameter with SUVmax 3.3. 


\section{Discussion}

Nakhoda et al., [7] estimated the sensitivity of FDG PET/CT for diagnosis of various renal masses and Takahashi et al., [8] tried to compare the behavior of different histological subtypes of RCC. FDG PET/CT is not helpful in diagnosis and staging of primary RCC [6]

Win and Aparici [9] recorded 100\% sensitivity and $100 \%$ specificity in recognition of all RCC metastatic lesions. This was confirmed by more recent study by Alongi et al., [10]

In this study RCC metastatic deposits response to TKI was assessed after studying 30 patients. All of received famous TKI named Sunitinib as Vercellino et al., [11], Revheim et al., [12] and Kayani et al., [13] did in their studies including 12, 14 (1 excluded case because of rapid status deterioration) and 44 (1 patient not performed because of negative baseline scan) patients respectively. Lyrdal et al., [14] and Khandani et al., [15] used Sorafenib studying 10 and 26 patients respectively.

Minamimoto et al., [16] studied 12 patients, 7 received Sorafenib and 5 received Sunitinib. Ueno et al., [17] studied 30 patients, 14 received Sorafenib and 16 received Sunitinib.

4 cycles of TKI therapy were administrated before the second PET/CT examination in this work. This is considered longer period than other studies in literature as longest reported was followed by Kayani et al., [13] who waited for 3 cycles before performance of second examination. The longer period was suggested by the medical oncologist who followed all patients as most of previous studies proposed to wait one cycle only. Prolonging the period till 4 cycles was risky giving chance for recurrences that could worsen the results.

According to the results, the disease regression in current study was relatively high $(22 / 30,73.3 \%)$ compared to other studies and represented the majority of cases matching with results of Revheim et al., [12] (6/13, 46.2\%), Kayani et al., [13] (24/43, $55.8 \%)$ and Ueno et al., [17] (12/30, 40\%). These results opposed the results of Vercellino et al., [11] $(4 / 12,33.3 \%)$ while the majority of cases in this study showed stationary course of the disease (7/12, $58.3 \%)$.

Stable appearance of the metastatic disease was recorded in many studies with different percentages. Ueno et al., [17] recorded $(10 / 30,33.3 \%)$ and Revheim et al., [12] recorded $(3 / 13,23 \%)$. These results were in concordance with those obtained in this work $(6 / 30,20 \%)$.

Unfortunately disease progression was noted in two cases of current work $(2 / 30,6.7 \%)$. This was close to results obtained by Kayani et al., [13] $(5 / 43,11.6 \%)$. These patients represented the least percent in many studies despite high percentage as recorded by Ueno et al., [17] $(8 / 30,26.7 \%)$. In the contrary, Lyrdal et al., [14] recorded 8 out of 12 cases with disease progression representing $80 \%$ of patients.

Caldarella [18] and his colleagues presented systematic review discussing seven published studies and found good correlation between metabolic response and progression free survival and/or overall survival. They also stated that the greatest post therapeutic reduction in SUVmax the higher the survival rates. During assessment of response of soft tissue and bony RCC metastasis after TKI treatment, these studies revealed high predictive value of FDG PET/CT.

Some studies compared the values of RECIST and FDG PET/CT in predicting progression free survival and overall survival of patients treated with TKI for metastatic RCC. Lyrdal et al., [19] stated that FDG PET/CT was superior to RECIST particularly regarding skeletal lesions. Kakizoe et al., [20] reported decrease of FDG accumulation 1 month after initiation of TKI treatment regardless site of metastasis. They recommended FDG PET/ $\mathrm{CT}$ as valuable modality for follow-up to observe response to TKI.

Limited spatial resolution of PET/CT and faint FDG uptake by some tumors are considered limitations. The use of specific PET tracers, such as C 11-methionine and C 11-choline could be suggested but their short half-lives prevent their routine use.

The updated international guidelines do not recommend the use of FDG PET/CT in detection and staging primary RCC [21,22], however, it can effectively be used for post operative observation and restaging [23]. In conclusion ${ }^{18} \mathrm{~F}$-FDG PET/CT is an effective index in monitoring efficacy of TKI treatment for RCC metastasis.

\section{References}

1- FUCCIO C., CECI F., CASTELLUCCI P., SPINAPOLICE E.G., PALUMBO R., D'AMBROSIO D., et al.: Restaging clear cell renal carcinoma with ${ }^{18} \mathrm{~F}-\mathrm{FDG}$ PET/CT. Clin Nucl. Med., 39: e320-4, 2014.

2- RINI B., RATHMELL W. and GODLEY P.: Renal cell carcinoma. Curr. Opin. Oncol., 20: 300-6, 2008. 
3- BERTAGNA F., MOTTA F., BERTOLI M., BOSIO G., FISOGNI S., TARDANICO R., et al.: Role of $\mathrm{F}^{18}$-FDG$\mathrm{PET} / \mathrm{CT}$ in restaging patients affected by renal carcinoma. Nucl. Med. Rev. Cent. East. Eur., 16 (1): 3-8, 2013.

4- WANG H., DING H., CHEN J., CHAO C., LU Y., LIN W., et al.: Meta-analysis of the diagnostic performance of $\left[{ }^{18} \mathrm{~F}\right] \mathrm{FDG}-\mathrm{PET}$ and PET/CT in renal cell carcinoma. Cancer Imaging, 12: 464-74, 2012.

5- ANANDAPPA G., HOLLINGDALE A. and EISEN T.: Everolimus-a new approach in the treatment of renal cell carcinoma. Cancer Manag. Res., 2: 61-70, 2010.

6- LIU Y.: The Place of FDG PET/CT in Renal Cell Carcinoma: Value and Limitations. Front. Oncol., 6: 201, 2016.

7- NAKHODA Z., TORIGIAN D.A., SABOURY B., HOFHEINZ F. and ALAVI A.: Assessment of the diagnostic performance of ( $)$ F-FDG-PET/CT for detection and characterization of solid renal malignancies. Hell J. Nucl. Med., 16: 19-24. Doi:10.1967/s002449910067, 2013.

8- TAKAHASHI M., KUME H., KOYAMA K., NAKAGAWA T., FUJIMURA T., MORIKAWA T., et al.: Preoperative evaluation of renal cell carcinoma by using 18F-FDG PET/CT. Clin. Nucl. Med., 40: 936-40. Doi: 10.1097/RLU.0000000000000875, 2015.

9- WIN A.Z. and APARICI C.M.: Clinical effectiveness of $\left({ }^{8}\right)$ F-fluorodeoxyglucose positron emission tomography/computed tomography in management of renal cell carcinoma: A single institution experience. World J. Nucl. Med., 14: 36-40. Doi: 10.4103/1450-1147.150535, 2015.

10- ALONGI P., PICCHIO M., ZATTONI F., SPALLINO M., GIANOLLI L., SALADINI G., et al.: Recurrent renal cell carcinoma: Clinical and prognostic value of FDG PET/CT. Eur. J. Nucl. Med. Mol. Imaging, 43: 464-73. Doi: 10. 1007/s00259-015-3 159-6, 2016.

11-VERCELLINO L., BOUSQUET G., BAILLET G., BARRÉ E., MATHIEU O., JUST P.A., et al.: ${ }^{18}$ F-FDG PET/CT imaging for an early assessment of response to sunitinib in metastatic renal carcinoma: Preliminary study. Cancer Biother. Radiopharm., 24: 137-44,2009.

12- REVHEIM M.E., WINGE-MAIN A.K., HAGEN G., FJELD J.G., FOSSÅ S.D. and LILLEBY W.: Combined positron emission tomography/computed tomography in sunitinib therapy assessment of patients with metastatic renal cell carcinoma. Clin. Oncol. (R. Coll. Radiol.), 23: 339-43, 2011.

13- KAYANI I., AVRIL N., BOMANJI J., CHOWDHURY S., ROCKALL A., SAHDEV A., et al.: Sequential FDG$\mathrm{PET} / \mathrm{CT}$ as a biomarker of response to Sunitinib in metastatic clear cell renal cancer. Clin. Cancer Res., 17: 60218, 2011.

14- LYRDAL D., BOIJSEN M., SUURKÜLA M., LUNDSTAM S. and STIERNER U.: Evaluation of sorafenib treatment in metastatic renal cell carcinoma with 2-fluoro2-deoxyglucose positron emission tomography and computed tomography. Nucl. Med. Commun., 30: 519-24, 2009.

15- KHANDANI A.H., COWEY C.L., MOORE D.T., GOHIL H. and RATHMELL W.K.: Primary renal cell carcinoma: Relationship between ${ }^{18}$ F-FDG uptake and response to neoadjuvant sorafenib. Nucl. Med. Commun., 33: $967-$ 73, 2012.

16- MINAMIMOTO R., NAKAIGAWA N., TATEISHI U., SUZUKI A., SHIZUKUISHI K., KISHIDA T., et al.: Evaluation of response to multikinase inhibitor in metastatic renal cell carcinoma by FDG PET/contrast-enhanced CT. Clin. Nucl. Med., 35: 918-23, 2010.

17- UENO D., YAO M., TATEISHI U., MINAMIMOTO R., MAKIYAMA K., HAYASHI N., et al.: Early assessment by FDG-PET/CT of patients with advanced renal cell carcinoma treated with tyrosine kinase inhibitors is predictive of disease course. B.M.C. Cancer, 12: 162, 2012.

18- CALDARELLA C., MUOIO B., ISGRO M.A., PORFIRI E., TREGLIA G. and GIOVANELLA L.: The role of fluorine- ${ }^{18}$-fluorodeoxyglucose positron emission tomography in evaluating the response to tyrosine-kinase inhibitors in patients with metastatic primary renal cell carcinoma. Radiol. Oncol., 48: 219-27. Doi:10.2478/raon2013-0067, 2014.

19- LYRDAL D., BOIJSEN M., SUURKULA M., LUNDSTAM S. and STIERNER U.: Evaluation of sorafenib treatment in metastatic renal cell carcinoma with 2-fluoro2-deoxy-glucose positron emission tomography and computed tomography. Nucl. Med. Commun., 30: 519-24. Doi: 10.1 097/MNM.0b01 3e32832cc220, 2009.

20- KAKIZOE M., YAO M., TATEISHI U., MINAMIMOTO R., UENO D., NAMURA K., et al.: The early response of renal cell carcinoma to tyrosine kinase inhibitors evaluated by FDG PET/CT was not influenced by metastatic organ. B.M.C. Cancer, 14:390. Doi: 10.1186/14712407-14-390, 2014.

21- BOELLAARD R., DELGADO-BOLTON R., OYEN W.J., GIAMMARILE F., TATSCH K., ESCHNER W., et al.: FDG PET/CT: EANM procedure guidelines for tumour imaging: Version 2.0. Eur. J. Nucl. Med. Mol. Imaging, 42: 328-54. Doi:10.1007/ s00259-014-2961-x, 2015.

22- ESCUDIER B., PORTA C., SCHMIDINGER M., ALGABA F., PATARD J.J., KHOO V., et al.: Renal cell carcinoma: ESMO Clinical Practice Guidelines for diagnosis, treatment and follow-up. Ann. Oncol., 25 (Suppl 3): iii4956. Doi: 10.1093/annonc/ mdu259, 2014.

23- BOUCHELOUCHE K. and CHOYKE P.L.: PET/computed tomography in renal, bladder, and testicular cancer. PET Clin., 10: 361-74. Doi:10.1016/j.cpet.2015.03.002, 2015. 


\section{الكفاءة العلاجية لموانع التيروزين كاينيز فى علاج ثانويات آورام الكلى الخبيثة

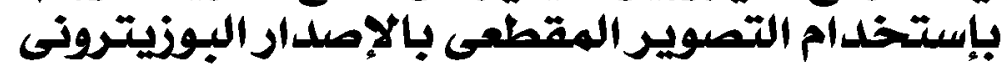

الهدف:كان الهدف من هذه الدراسة هو إستخدام التصوير المقطعى بالإصدار البوزيترونى كمؤثر لتقييم إستجابة ثانويات آودام الكلى الخبيثة للعلاج بموانع التيروزين كاينيز.

مرضى وطرق: ثلاثون مريضا يعانون من ثانويات آودام الكلى الخييثة بعد إستئمال كلى للكلى آجرا فحص التصوير المقطعى بالإصدار

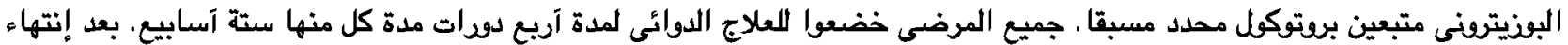
المدة جميعهم آجرا فحص ثانى للتصوير المقطعى بالإصدار البوزيترونى متبعين نفس البروتوكلل بعد ستة آثنهر لتقييم مدى الإستجابة للعلاج.

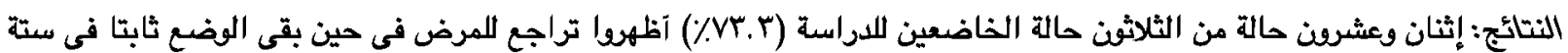

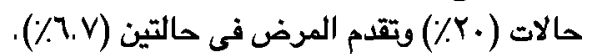

إستتاج: التصوير المقطعى بالإصدار البونيترونى هو مؤشر فعال فى مراقبة فعالية علاج ثانويات آودام الكلى الخبيثة بإستخدام موانع التيروزين كاينيز. 